\title{
Study of demographic features in retropositive pregnant women
}

\author{
Saravana A., Shashikala B. Patil*, K. S. Rashmi
}

Department of Obstetrics and Gynaecology, BGS Global Institute of Medical Sciences Medical College, Bengaluru, Karnataka, India

Received: 10 August 2016

Accepted: 06 September 2016

\section{*Correspondence:}

Dr. Shashikala B. Patil,

E-mail: drshashika@gmail.com

Copyright: (C) the author(s), publisher and licensee Medip Academy. This is an open-access article distributed under the terms of the Creative Commons Attribution Non-Commercial License, which permits unrestricted non-commercial use, distribution, and reproduction in any medium, provided the original work is properly cited.

\section{ABSTRACT}

Background: Study of demographic features like age, educational status of the patient and her husband, occupation of the patient and her husband and religion of the retropositive pregnant women compared to controls.

Methods: In this prospective study patients were selected from Vani Vilas Hospital attached to Bangalore Medical College attending the antenatal Clinic of Obstetrics and Gynaecology. The study period was for 2 years. The study group comprised of 100 HIV seropositive patients. The control group comprised of 100 HIV seronegative patients. At enrollment, data collection of demographic features like age, educational status of the patient and her husband, occupation of patient and her husband, and religion of the retropositive pregnant women compared to controls.

Results: The minimum and maximum age in the study group was 18 and 36 years respectively and in the control group 17 and 35 years respectively. Around $73 \%$ of pregnant women in the study group were below 25 years of age. $89 \%$ of pregnant women in the study group were Hindus. Around $36 \%$ of women in the study group were illiterate compared to $21 \%$ in the control group. Around $45 \%$ of women in the control group have studied till secondary school. In this study, most of the women in both the groups were housewives. There was one commercial sex worker and 8 women had polygamous relationship in the study group. The occupational pattern of the husbands was analyzed and $34 \%$ of the husbands of HIV positive women were drivers. $56 \%$ of the husbands in the study group admitted to have had multiple sexual partners, whereas only $9 \%$ admitted so, in the control group.

Conclusions: Retropositive pregnant women were younger; most of them were house wives. Husbands of retropositive pregnant women were drivers and most of them had multiple sexual partners.

Keywords: Demographic features, Retropositive, Pregnant women

\section{INTRODUCTION}

Human immuno deficiency virus, HIV is now established as the primary cause of acquired immuno deficiency syndrome. HIV has a dramatic impact on the health of women, infants and children. ${ }^{1}$

India carries the largest burden of HIV in Asia and is the third country of the world in terms of the number of people living with HIV. Increasing numbers of women are HIV-infected worldwide and within the Indian context, women account for an estimated $40 \%$ of cases among the 2.5 million people living with HIV/AIDS. ${ }^{2}$
In India, women account for around 1 million out of the 2.5 million estimated numbers of people living with HIV/AIDS. ${ }^{3}$ Study of demographic features like age, educational status of the patient and her husband, occupation of patient and her husband, and religion of the pregnant retropositive pregnant women compared to controls.

\section{METHODS}

In this prospective study patients were selected from Vani Vilas Hospital attached to Bangalore Medical College attending the antenatal Clinic of Obstetrics and Gynaecology, India. The study period was for 2 years. 
Department of Vani Vilas Hospital were recruited and after a proper pre-test counseling by experienced counselors, the informed written consent for conducting the HIV test was taken. Diagnosis of HIV seropositive was made as per the NACO guidelines, using rapid tests. The study group comprised of 100 HIV seropositive patients. The control group comprised of 100 HIV seronegative patients. Inclusion criteria was willing to get enrolled in the study. Informed written consent was taken. Exclusion criteria was women with bad obstetric history and women not willing to get enrolled in the study.

At enrollment, data collection of demographic features like age, educational status of the patient and her husband, occupation of patient and her husband, and religion of the pregnant retropositive pregnant women compared to controls.

\section{RESULTS}

A prospective comparative study consisting of $100 \mathrm{HIV}$ seropositive pregnant women as study group and 100 HIV seronegative pregnant women as controls.

Table 1:Age distribution.

\begin{tabular}{|c|c|c|c|c|}
\hline $\begin{array}{l}\text { Age } \\
\text { in } \\
\text { years }\end{array}$ & $\begin{array}{l}\text { HIV } \\
\text { positive }\end{array}$ & $\begin{array}{l}\text { HIV } \\
\text { negative }\end{array}$ & Significance & $\mathbf{R} \mathbf{R}$ \\
\hline $15-19$ & $13(13.0)$ & $8(8.0)$ & $\mathrm{P}=0.249$ & 1.27 \\
\hline $20-25$ & $60(60.0)$ & $80(80.0)$ & $\mathrm{P}=0.003$ & 0.64 \\
\hline $26-30$ & $22(22.0)$ & $11(11.0)$ & $\mathrm{P}=0.056$ & 1.42 \\
\hline$>30$ & $5(5.0)$ & $1(1.0)$ & $\mathrm{P}=0.212$ & 1.69 \\
\hline Total & 100 & 100 & & \\
\hline
\end{tabular}

The minimum and maximum age in the study group was 18 and 36 years respectively, and in the control group 17 and 35 years respectively. Around $73 \%$ of pregnant women in the study group were below 25 years of age.

Table 2: Religion wise distribution.

\begin{tabular}{|lllll|}
\hline Religion & $\begin{array}{l}\text { HIV } \\
\text { positive }\end{array}$ & $\begin{array}{l}\text { HIV } \\
\text { negative }\end{array}$ & Significance & RR \\
\hline Christian & - & $3(3.0)$ & $\mathrm{P}=0.246$ & - \\
\hline Hindu & $89(89.0)$ & $78(78.0)$ & $\mathrm{P}=0.036$ & 1.61 \\
\hline Muslim & $11(11.0)$ & $19(19.0)$ & $\mathrm{P}=0.113$ & 0.71 \\
\hline Total & 100 & 100 & & \\
\hline
\end{tabular}

$89 \%$ of pregnant women in the study group were hindus.

Around $36 \%$ of women are illiterate in the study group and is significantly different from the control group. Around $45 \%$ of women in the control group have studied till secondary, which is also statistically significant at $\mathrm{P}<0.05$
Table 3: Educational status of women

\begin{tabular}{|lllll|}
\hline $\begin{array}{l}\text { Education } \\
\text { (Women) }\end{array}$ & $\begin{array}{l}\text { HIV } \\
\text { positive }\end{array}$ & $\begin{array}{l}\text { HIV } \\
\text { negative }\end{array}$ & Significance & RR \\
\hline Illiterate & $36(36.0)$ & $21(21.0)$ & $\mathrm{P}=0.019$ & 1.43 \\
\hline Primary & $19(19.0)$ & $23(23.0)$ & $\mathrm{P}=0.487$ & 0.88 \\
\hline Secondary & $31(31.0)$ & $45(45.0)$ & $\mathrm{P}=0.041$ & 0.73 \\
\hline College & $14(14.0)$ & $11(11.0)$ & $\mathrm{P}=0.521$ & 1.14 \\
\hline Total & 100 & 100 & & \\
\hline
\end{tabular}

Table 4: Educational status of the husband.

\begin{tabular}{|lllll|}
\hline $\begin{array}{l}\text { Education } \\
\text { (husband) }\end{array}$ & $\begin{array}{l}\text { HIV } \\
\text { positive }\end{array}$ & $\begin{array}{l}\text { HIV } \\
\text { negative }\end{array}$ & Significance & RR \\
\hline Illiterate & $\begin{array}{l}31 \\
(31.0)\end{array}$ & $\begin{array}{l}26 \\
(26.0)\end{array}$ & $\mathrm{P}=0.434$ & 1.15 \\
\hline Primary & $\begin{array}{l}19 \\
(19.0)\end{array}$ & $\begin{array}{l}21 \\
(21.0)\end{array}$ & $\mathrm{P}=0.724$ & 1.48 \\
\hline Secondary & $\begin{array}{l}37 \\
(37.0)\end{array}$ & $\begin{array}{l}38 \\
(38.0)\end{array}$ & $\mathrm{P}=0.884$ & 0.98 \\
\hline College & $\begin{array}{l}13 \\
(13.0)\end{array}$ & $\begin{array}{l}15 \\
(15.0)\end{array}$ & $\mathrm{P}=0.684$ & 0.91 \\
\hline Total & 100 & 100 & & \\
\hline
\end{tabular}

There was no statistical difference between study and control group.

Table 5: Occupational distribution of women.

\begin{tabular}{|lll|}
\hline Occupation (women) & HIV positive & HIV negative \\
\hline Beedi worker & - & 1 \\
\hline CSW & 1 & - \\
\hline Garment factory & 1 & 2 \\
\hline House wife & 94 & 92 \\
\hline Pharmacist & - & 1 \\
\hline Staff nurse & 1 & 2 \\
\hline Teacher & 3 & 2 \\
\hline Total & 100 & 100 \\
\hline
\end{tabular}

Table 6: Occupation of the husband.

\begin{tabular}{|llll|}
\hline $\begin{array}{l}\text { Occupation } \\
\text { (husband) }\end{array}$ & $\begin{array}{l}\text { HIV } \\
\text { positive }\end{array}$ & $\begin{array}{l}\text { HIV } \\
\text { negative }\end{array}$ & Significance \\
\hline $\begin{array}{l}\text { Agriculture } \\
\text { and farmers }\end{array}$ & 20 & 17 & $\mathrm{P}=0.585$ \\
\hline $\begin{array}{l}\text { Truck/ auto/ } \\
\text { taxi driver } \\
\text { /cleaner }\end{array}$ & 35 & 8 & $\mathrm{P}=0.000$ \\
\hline $\begin{array}{l}\text { Unskilled } \\
\text { worker }\end{array}$ & 27 & 41 & \\
\hline $\begin{array}{l}\text { Industrial } \\
\text { and factory } \\
\text { worker }\end{array}$ & 2 & 16 & - \\
\hline Hotel & 3 & 3 & - \\
\hline Business & 5 & 7 & - \\
\hline Others & 8 & 8 & - \\
\hline
\end{tabular}


Most of the women in both the study and control group were housewives. There was one commercial sex worker in the study group.

In terms of occupation of husband $35 \%$ were drivers in the study group whereas in the control group there were only $8 \%$ including $2 \%$ cleaners, which is statistically significant $(\mathrm{P}<0.05)$.

\section{DISCUSSION}

In the present study, 100 HIV seropositive pregnant women were compared with 100 HIV seronegative pregnant women. The focus for evaluation was mainly demographic characteristics like age, educational status of the patient and her husband, occupation of patient and her husband and religion of the retropositive pregnant women compared to controls.

All the pregnant women were aged between 17 and 36 years. The minimum and maximum age in the study group was 18 and 36 years respectively, and in the control group 17 and 35 years respectively. Around 73\% pregnant women in this study group were below 25 years of age.

The educational status of both the women and their partners was studied. Around $36 \%$ of women in the study group were illiterate compared to $21 \%$ in the control group. Around $45 \%$ of women in the control group have studied till secondary school. However, there are a good number of women who have studied till college in both the groups. Moreover, in the study there was no significant difference in the educational status of the husbands.

In this study, most of the women in both the groups were housewives. There was one commercial sex worker and 8 women had polygamous relationship in the study group.

These findings are in agreement with those of study by Chauhan $\mathrm{G}$ et al who found that $81 \%$ were housewives and $88 \%$ to be monogamous in a study in Tamil Nadu characterizing $134 \mathrm{HIV}$ positive women. ${ }^{4}$

In recent years, married monogamous women have been identified as a population at increasing risk for HIV in India. Most of the risk factors for HIV-1 infection in our population are related to sexual risk behavior, including age at sexual debut, number of sexual partners and a history of STDs. In India, drivers and commercial sex workers are at higher risk for HIV infection than other population groups. HIV positive women were found to have significantly more STDs than HIV negative women.
Around $15 \%$ of HIV positive women had additional STDs compared to only $3 \%$ of HIV negative women.

These findings are comparable to other studies. Minkoff et al, reported that seropositive mothers were significantly more likely to have sexually transmitted diseases. ${ }^{5}$ A study conducted in India by Patel $\mathrm{M}$ et al, reported that $20.7 \%$ HIV positive women had additional sexually transmitted diseases compared to only $4.6 \% \mathrm{HIV}$ negative women. ${ }^{6}$

The occupational pattern of the husbands was analyzed and $34 \%$ of the husbands of HIV positive women were drivers. $56 \%$ of the husbands in the study group admitted to have had multiple sexual partners, whereas only $9 \%$ admitted so, in the control group. Only $6 \%$ of both the partners had polygamous relation in the study group.

\section{CONCLUSION}

Retropositive pregnant women were younger, most of them were house wives. Husbands of retropositive pregnant women were drivers and most of them had multiple sexual partners.

Funding: No funding sources

Conflict of interest: None declared

Ethical approval: The study was approved by the Institutional Ethics Committee

\section{REFERENCES}

1. The Joint United Nations Programme on HIV/AIDS and World Health Organization (UNAIDS/WHO). Available at: http:// www.unaids.org / en / dataanalysis/monitoringcountryprogress/2010progres sreportssubmittedbycountries/india_2010_country_p rogress_report_en.pdf. Accessed on 22 July 2011.

2. National AIDS Control Organization. UNGASS Country Progress Report 2008, Delhi, India.

3. National AIDS Control Organization. Available at: http://www.nacoonline.org/Quick_Links/Women/25/ 07/09. Accessed on 07 July 2009.

4. Chauhan G, Verma A, Bansal RK, Prasad R. Socio demographic and clinical profile of hiv positive antenatal women registered in PPTCT centres, Surat, Gujarat. Natl J Community Med. 2014:5(3);337-41.

5. Minkoff $\mathrm{H}$, Henderson $\mathrm{C}$, Mendez H. Pregnancy outcome among mothers infected with Human immuno deficiency virus and uninfected control subjects. Am J Obstet Gynecol. 1990;163:1598-604.

6. Madhuri P, Kavitha K. Bharucha E. Pregnancy outcome in HIV seropositive women. J Obstet Gynecol India. 2000;50:48-52.

Cite this article as: Saravana A, Patil SB, Rashmi KS. Study of demographic features in retropositive pregnant women. Int J Reprod Contracept Obstet Gynecol 2016;5:3529-31. 